\title{
The Effects of Spiritual Intelligence and its Dimensions on Organizational Citizenship Behaviour
}

\author{
Md. Aftab Anwar, AAhad M. Osman-Gani \\ International Islamic University Malaysia, Malaysia (Malaysia) \\ zitu6th@yahoo.com,aahad@iumm.edu.my
}

Received: April 2015

Accepted: July 2015

\section{Abstract:}

Purpose: Organizational citizenship behaviour may exist among employees who have inner feelings of having better work experiences by using their spiritual experiences, and also to nurture these by creating meaningful ethical work environments. These phenomena have not been sufficiently studied especially in the context of recent corporate scandals and ethical violations. For this reason, this study seeks to enrich the understanding of relationship of spiritual intelligence and its sub constructs on employee citizenship behaviour among the employees who are working in manufacturing and service organization in Malaysia.

Design/methodology/approach: This paper examines the effect of spiritual intelligence and its dimensions on organizational citizenship behaviour among the employees who are working in manufacturing and service industries in Malaysia. Data were collected from 112 employees of the organization from 10 manufacturing and 10 service organization in Peninsular Malaysia.

Findings: Multiple regression analyses have revealed that employee spiritual intelligence plays an important role for generating citizenship behaviour among employees. The two important dimensions namely critical existential thinking and transcendental awareness of spiritual intelligence are having great effect on organizational citizenship behaviour.

Research limitations/implications: Scholars can develop new research agenda first to identify the nature of effects it might have on employee's performance which can boost the ultimate goal of the organization. 
Practical implications: Through the finding of this empirical study, it is hoped that it can provide some preliminary assessment and knowledge of the effects of spiritual intelligence of employees and how they relate to the OCB. This would be vital for industrial development by adding relevant policies regarding enhancing employees' OCB.

Social implications: This study has the capacity to enhance management awareness concerning recruiting people in terms of spiritual intelligence. People from different culture with high level of citizenship behavior can able to get the job.

Originality/value: Organizational management may consider making appropriate decisions for nurturing and developing the relevant dimensions of this intelligence that are lacking among the employees in order to inculcate the spirit of OCB and develop a better work environment. Implications of the research findings for management scholars as well as for management professionals are discussed at the end.

Keywords: spiritual intelligence, organization, citizenship, behavior

\section{Introduction}

Organizational citizenship behaviour (OCB) is a voluntary behaviour that improves organizational effectiveness, and it goes beyond formal duties or roles of employees (Kwon Choi, Koo Moon, Ko, \& Min Kim, 2014; Organ, 1990). Until now, OCB has not been considered as an integral part of organizational formal rules and regulations, but was found to have greater impact on organizational efficiency (Organ, Podsakoff \& MacKenzie, 2006). Moreover, OCB has casual effect on employee job satisfaction, whereby satisfied employees showed low absenteeism and turnover (Organ, 1988).

Spiritual intelligence deals with the mental aptitude of realization for 'being in existence' and the 'meaning of life'. Previous research has shown the contribution of individual spiritual components of employees to their performance within the organization (Zohar \& Marshall, 2004). However, rare studies have been conducted empirically to confirm how this intelligence can have effects on their citizenship behaviour. Therefore, there exists a significant research gap, and it is important to understand the nature of relationship existing between spiritual intelligence and organizational citizenship behaviour of employees. This study aimed to identify the effects of spiritual intelligence and its dimensions on organizational citizenship behaviour (OCB).

Previous researches have shown that individual work involvement and job motivation are highly linked with their spiritual experiences at the workplace (Jeloudar \& Goodarzi, 2012). 
With higher level of spirituality; individuals can have better internal inspirational motivation for devotion to their work. In this process, better outcome produces and improves organizational performance. Hence, an individual with good level of spiritual intelligence might be an asset for the organization. For this reason, it is necessary to understand the effects of spiritual intelligence on OCB in the workplace (Doostar, Chegini \& Pourabbasi, 2012). This study empirically investigates the effects of spiritual intelligence on OCB, and also examines the effects of the specific dimensions of SI on OCB.

A number of study have revealed the various antecedents of OCB in the organization, such as, employees self-characteristics, organizational justice, leadership characteristics and style, influence of culture, job satisfaction personality and spirituality (Kamil, 2012; Salehi \& Gholtash, 2011). In particular, a rare study has been conducted to understand human intelligence as the antecedents of OCB in the workplace. Management scholars are now looking for clear understandings of this construct that can provide a significant knowledge of individual spiritual experience in response to organizational relationship (Osman-Gani, \& Sarif, 2011). However, multiple intelligences are found to be closely associated with the organizational affairs (Gardner, 1983; Sonboli \& Noruzi, 2012). Weller (1999) mentioned the importance of multiple intelligences for developing high quality for developing a conceptually sound framework to understand why OCB occurs and its effects on employees and organizations, especially in service and manufacturing sector.

Recently, both manufacturing and service industries are considered as one of the most significant source of Malaysia's economic diversification strategy as well as these sectors are playing a substantial role in the development of Malaysian economy for few decades (Lo \& Ramayah, 2009). Both sectors will remain as the essential source to expand the growth of Malaysian economy. Management are required to focus on developing human resource skills and capacity to sustain their competitiveness in the global market competition. According to Abdullah (1996), employees working in manufacturing and service industries are required more skill for interpersonal communication, social interaction, face work related stress in terms of cross cultural aspects. For this reason, it is necessary to identify how and in what level people can identify them to assess their existence on earth, life time objectives, self-awareness towards existence and to transcendent spiritual experiences while they work in a particular work environment. Although, there has been conducted a number of study to understand the antecedents of $O C B$, but, a very rare study conducted to identify the effects of spiritual intelligence, especially in Malaysian context. 


\section{Literature Review}

\subsection{Spiritual Intelligence (SI)}

The concept of spiritual intelligence was first proposed by Gardner (1998) in the theory of 'multiple intelligences'. Later on, 'spiritual intelligence' was termed by Zohar and Marshall (1997). Since the development of this construct researchers have been searching for the contribution of spiritual intelligence from organizational perspectives (Zohar \& Drake, 2000; Shabani, Hassan, Ahmad \& Baba, 2011). Emmons (2000) claimed that individual spirituality can help people to develop their decision making skill and goal attaining capacities through employing self-existence awareness and personal meaning production (Shabani et al., 2011). Spiritual intelligence is not only the combination of the term 'spirituality' and 'intelligence' but also represents the spontaneous guidance by bringing forth the originality and holistic approach of the concepts (Zohar \& Drake, 2000). Individual spirituality influences employee performance which has empirically confirmed (Osman-Gani, Hashim \& Ismail 2013).

Zohar and Marshall (1997) defined spiritual intelligence as to identify the life as 'meaning', 'purpose' and 'values' that connects the meaning of peoples' activities and intellectual capabilities that deals with the question of human existence. Noble (2000) mentioned that individual spiritual intelligence is an inborn capability that helps people for psychological growth. A matured and psychologically sound person can become a best asset for any organization. For this reason, it is necessary to understand the contribution of spiritual intelligence on individual behaviour in the workplace setting which can contribute a greater knowledge in the fields of management and psychology.

King (2008) has identified the four main dimensions of spiritual intelligence. The dimensions are namely critical existential thinking, personal meaning of production, transcendental awareness and conscious state expansion. Critical existential thinking (CET) means ability to think the meaning of life, reason and other existential/otherworldly issues (e.g., presence, reality, demise, the universe). In addition to that, it is the ability to think about non-existential issues in association to one's existence to death. The another dimension proposed by King (2008) is personal meaning production (PMP), which is the capacity to infer individual importance and reason from all physical \& mental encounters, including the ability to produce and expert an existence reason. Another dimension of spiritual intelligence is transcendental awareness (TA), the ability to recognize magnificent measurements of the self, of others, and of the physical world amid typical conditions of awareness, joined by the ability to recognize their connection to one's self and to the physical. The final dimension conscious state expansion (CSE) is capacity to move around higher level of spiritual awareness at one's own discretion. 


\subsection{Organizational Citizenship Behaviour (OCB)}

OCB explains behaviour which permits the organization through strengthening and maintaining its social system (Sonboli \& Noruzi, 2012). Organ (1988: page 4) mentioned about OCB as the "individual behaviour that is discretionary, not directly or explicitly recognized by the formal reward system and that in the aggregate promotes the effective functioning of the organization". Previous research claimed that organizational citizenship behaviour is mainly caused by both explicitly and implicitly, and is influenced by the response of organizational environment or individual's own perception towards their job (Kumar \& Raj, 2009). Although OCB has greater influence over the workplace environment, but, still it is not considered as the part of the core job. For this reason, organizational management faces problems to compensate a good citizenship for their helping behaviour. A good citizen is an employee who presents support to the business organization even when there is no such support is or can be overtly necessary.

Organ (1990) described five categories of OCB: (1) Conscientiousness, or organizational loyalty (Graham, 1991) describe the obedience towards organization and dedication to the job which exceed formal activities such as working long hours, and volunteer to perform jobs besides duties (Organ, 1988). Lo \& Ramayah, (2009) expressed conscientiousness as organized, accountable and hardworking behavior of individual person. (2) Altruism, identified as most vital and common dimensions of OCB that acknowledged by the most researchers (Borman \& Motowidlo, 1997; Organ, 1990; Smith, Organ, \& Near, 1983; Williams \& Anderson, 1991); (3) Civic virtue promotes employees by involving them in organizational development activities. Deluga (1995) mentioned civic virtue as the voluntary attendance of employees in management activities and functional development; (4) Sportsmanship increases the constructive activities for the organization (Jahangir, Akbar \& Haq, 2004) which are tolerating the inevitable inconveniences and impositions of work without whining and grievances (Modassir \& Singh, 2008).; (5) Courtesy increases the communication among the co-workers and minimize the risk of conflict with the organization (Podsakoff, McKenzie, Paine \& Bachrach, 2000).

\subsection{Relationship between SI and OCB}

Faribors, Fatemeh and Hamidreza (2010) claimed that spiritually intelligent employees are happy enough to do their work properly. When an individual experiences cheerful in his/her mind may also become happy in their job, in this way, people become more useful for their organization and for the peer groups. According to Allameh, Amirosadat and Najafabadi (2012), the dimensions of spiritual intelligence and organizational justice are positively related. Organizational justice is one form of social exchange which is related with the employee's organizational citizenship behaviour. 
George (2006: page 3) claimed that SI helps in identifying and aligning personal values of the employee with a clear sense of purpose. He also highlighted that with the help of spiritual experiences employees would be able to recognize a high level of integrity, understanding of "true cause". Researchers have conducted conceptual analysis and empirical investigations and proposed relationships existing between the level of employees' spiritual intelligence and their performance, when employee citizenship behaviour was found to mediate among this relationship (Osman-Gani \& Anwar, 2013; Osman-Gani \& Anwar, 2014).

Saidy; Hassan, Rahman, Jalil, Ismail and Krauss (2009) proclaimed that with a good and pure soul, students will be able to keep good attitudes and be able to practice well desired behaviours, which will enable them to control themselves from doing wrong things in terms of values and norms that could influence the positive performance outcome. However, according to Zohar, and Marshall (2000) spiritual intelligence refers to the development of one's longing and capacity for meaning, vision and value which facilitates a dialogue between reason and emotion, between mind and body, and which enables one to integrate the interpersonal and intrapersonal behaviour, to transcend the gap existing between self and others.

According to Wigglesworth (2002) spiritual intelligence is the capacity to act with kindness and astuteness while keeping up inward and external peace (poise) paying respect to the condition. However, it is an important that individual enrichment which empowers one to keep up both internal and external peace and showcase cherish paying little respect to the circumstances whether anxiety or intense clash. This could likewise help in refereeing and attaining to serene concurrence in the general public (Animasahun, 2007). Zohar and Marshall (2004) stated that in the organization spiritual plays very significant role. Spirituality being gives associations and individuals a completely distinctive method for knowing and encountering work which is a method for encountering work that does result in measurable business sector advantage (Aburdene, 2005). Hence, the hypotheses derived from the literature which listed as follows:

Hypothesis 1: Significance relationship exists among spiritual intelligence and organizational citizenship behaviour.

Hypothesis 1a: Significance relationship exists among Critical Existential Thinking (CET) and organizational citizenship behaviour.

Hypothesis 1b: Significance relationship exists among Personal Meaning Production (PMT) and organizational citizenship behaviour.

Hypothesis 1C: Significance relationship exists among Transcendental Awareness (TA) and organizational citizenship behaviour.

Hypothesis 1d: Significance relationship exists among Conscious State Expansion (CSE) and organizational citizenship behaviour. 


\section{Conceptual Framework}

The conceptual framework of the research is presented through Figure 1 . At the left side of the figure, there is independent variable: spiritual intelligence in rectangular boxes with its subdimensions. At the right side of the figure the dependent variable: organizational citizenship behaviour is shown in oval shape. The framework depicts the relationships among the interdependent variables and the dependent variable as indicated through the arrow marks.

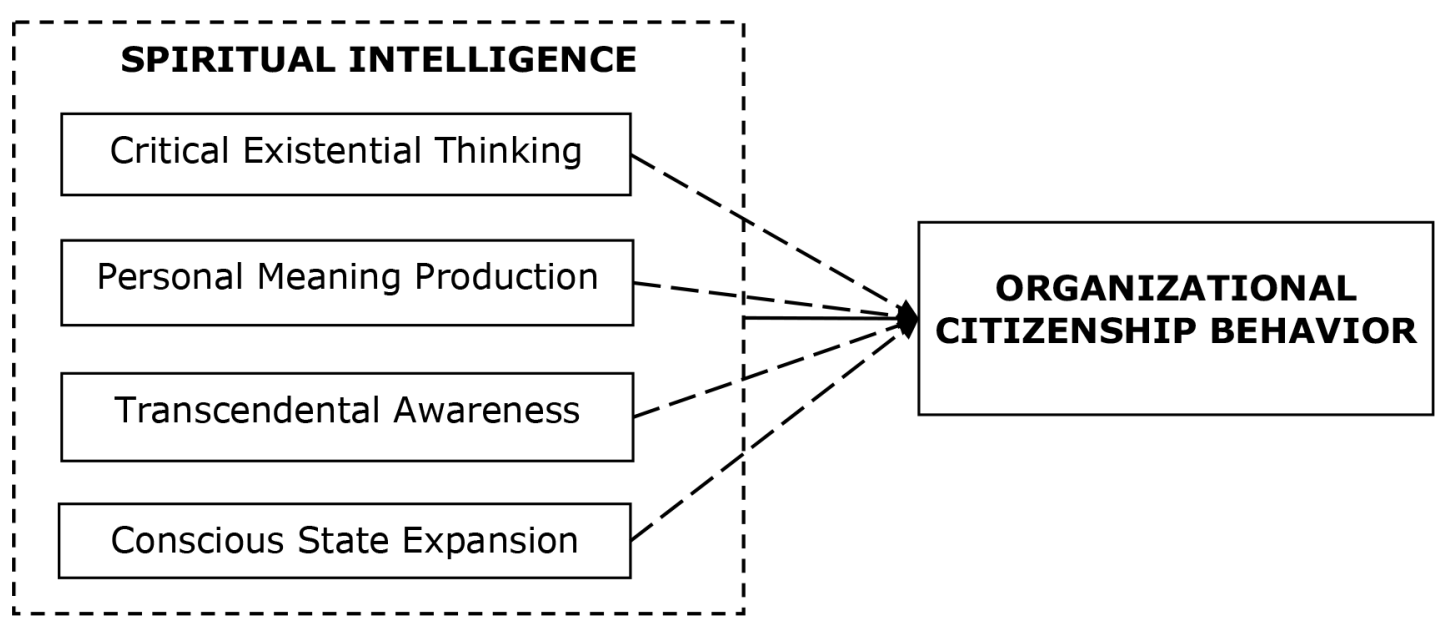

Figure 1. Conceptual Framework of the Research

\section{Method}

\subsection{Population and Sample}

The population for this study comprised of the employees working in the companies in manufacturing and service industries of Malaysia. The sample was selected from employees of manufacturing and service related organizations of Kuala Lumpur and Selangor areas of Malaysia. About ten manufacturing and ten service companies' was selected randomly and 15 employees were selected randomly from each of those 20 companies. The sample size of the study was 300. A survey was administered on the sample by using a structured questionnaire. The questionnaires were personally distributed to the employees, and the completed questionnaires were collected back after one week. A total 300 questionnaires were distributed among the employees and a total of 112 of completed questionnaires were collected by obtaining a response rate of $37.33 \%$. This was achieved after taking several follow up measures (e.g., phone calls, emails, visits) after the initial deadline, in order to improve the response rate. A total valid 107 questionnaire data were keyed in for data analysis. 


\subsection{Measures}

The study was conducted by using two different research instruments for measuring the two different constructs with four sub dimensions. The independent variables of the study are spiritual intelligence and its four components namely critical existential thinking, personal meaning production, transcendental awareness, conscious state expansion, and the dependent variable is organizational citizenship behaviour. The measures are based on a five point response scale ranging from 1 (strongly disagree) to 5 (strongly agree). The research incorporated the following established measured:

Spiritual intelligence - The measurement scale of spiritual intelligence has adapted from the scale of Spiritual Intelligence Self-Report Inventory (SISRI-24) by King (2008) with 24 items. The measurement of the scale consists of 5-point Rating-type scale, with responses ranging from 1 (Strongly Disagree) to 5 (Strongly Agree). Higher scores signify higher levels of spiritual intelligence or each capacity.

Organizational citizenship behaviour - The measuring instrument for OCB has adapted from the Podsakoff et al. (1990) OCB scale. The five dimensions of OCB are altruism, conscientiousness, sportsmanship, courtesy, and civic virtue that measure with this scale. The 24-items combined to measure the $O C B$ as a whole. According to the original OCB scale, it scored on a 7-point Likert-type scale, with responses ranging from '1' (Strongly Disagree) to ' 7 ' (Strongly Agree). But for this study, the scale adapted to 5 point rating scale which is ranging from ' 1 ' (Strongly Disagree) to ' 5 ' (Strongly Agree).

\section{Data Analysis}

The study conducted data analysis through SPSS version 19.0. To identify the respondents demographic information Table 1 represents the over scenario of respondents. A total number of 112 completed questionnaires were received, but only 107 questionnaires with valid information could be used. Data collected from both service (55\%) and manufacturing (45\%) industry companies included mostly local organizations (103), and the percentage of male respondent was 41.1 and the females were 58.9 percent. Most of the respondents are belongs to the age group of 25 to 34 years old. A total $52.3 \%$ of the respondents are married rests are single, widowed and divorced.

The Table 1 also represents that total number of 84 are Muslims, Christianity 15 and rests are belongs others religion. Most of the respondents have completed their bachelor degree only $4.7 \%$ have completed higher secondary level. Finally, the table also identified that the respondents mostly from first level employees only very few of them from top level. 


\begin{tabular}{|c|c|c|}
\hline Demographic Variables & Frequency & Percent $(\%)$ \\
\hline \multicolumn{3}{|l|}{ Gender } \\
\hline - Male & 44 & 41.1 \\
\hline - Female & 63 & 58.9 \\
\hline \multicolumn{3}{|l|}{ Age Group } \\
\hline - $\quad$ Below 25 & 17 & 15.9 \\
\hline - $25-34$ years & 54 & 50.5 \\
\hline - $35-44$ years & 22 & 20.6 \\
\hline - $45-54$ years & 11 & 10.3 \\
\hline - $55-64$ years & 3 & 2.8 \\
\hline - 65 years and above & 17 & 15.9 \\
\hline \multicolumn{3}{|l|}{ Marital Status } \\
\hline - $\quad$ Married & 56 & 52.3 \\
\hline - Unmarried & 47 & 43.9 \\
\hline - Widowed & 1 & 0.9 \\
\hline - Divorced/Separated & 3 & 2.8 \\
\hline \multicolumn{3}{|l|}{ Highest level of education } \\
\hline - $\quad$ Secondary & 5 & 4.7 \\
\hline - Diploma/ A Levels & 33 & 30.8 \\
\hline - Degree (Bachelor) & 50 & 46.7 \\
\hline - Masters & 19 & 17.8 \\
\hline \multicolumn{3}{|l|}{ Religion } \\
\hline - Islam & 84 & 78.5 \\
\hline - $\quad$ Buddhism & 3 & 2.8 \\
\hline - Christianity & 15 & 14.0 \\
\hline - Hinduism & 2 & 1.9 \\
\hline - Others & 3 & 2.8 \\
\hline \multicolumn{3}{|l|}{ Level of Employment } \\
\hline - $\quad$ First - level Management & 64 & 59.8 \\
\hline - Mid-Level Management & 34 & 31.8 \\
\hline - Top-level Management & 2 & 1.9 \\
\hline - Others & 7 & 6.5 \\
\hline
\end{tabular}

Table 1. Demographic Information of the Respondents

\section{Results and findings}

After collection of data, reliability tests were conducted through Statistical Package for Social Science, and computed the Cronbach's Alpha for each constructs. The questionnaire items relating to spiritual intelligence and organizational citizenship behaviour have passed the reliability tests, as all of them have obtained the scores 0.921 with 48 items. According to Hair, Black, Babin, Anderson and Tatham (2010) the minimum accepted alpha value should be 0.60 . 
The result of reliability test represent in the Table 2 . The following table below shows the Cronbach's Alpha values of the two variables of interest.

\begin{tabular}{|l|c|c|}
\hline Variables & Cronbach's Alpha & Item(s) \\
\hline Spiritual Intelligence (SI) & 0.878 & 24 \\
\hline Organizational Citizenship behavior (OCB) & 0.899 & 24 \\
\hline
\end{tabular}

Table 2. Reliability Test Results

The correlation and regression analyses were conducted to identify the relationship existing among the dependent and independent variables of the study. The results showed that the components of organizational citizenship behaviour are positively correlated with spiritual intelligence.

\begin{tabular}{|c|c|c|c|c|}
\hline \multicolumn{5}{|c|}{ Model Summary ${ }^{b}$} \\
\hline Model & $\mathrm{R}$ & R Square & Adjusted R Square & Std. Error of the Estimate \\
\hline & $.498^{\mathrm{a}}$ & .248 & .241 & .41380 \\
\hline
\end{tabular}

aPredictors: (Constant), SI; 'Dependent Variable: OCB

Table 3. Correlation among SI and OCB

Table 3 shows the correlation coefficients among the dimensions of spiritual intelligence and the organizational citizenship behaviour. The Table 3 represents that $R$ Square is 0.248 for the regression of organizational citizenship behaviour of 0.498 . This means that $24.8 \%$ of the variation in the organizational citizenship behavior be explained by the spiritual intelligence. The others $75.2 \%$ remain unexplained.

\begin{tabular}{|c|c|c|c|c|c|c|c|}
\hline Variables & Mean & Std. Deviation & CET & PMP & TA & CSE & OCB \\
\hline CET & 3.50 & .438 & 1 & & & & \\
\hline PMP & 3.76 & .566 & $.436^{* *}$ & 1 & & & \\
\hline TA & 3.64 & .538 & $.597^{* *}$ & $.584^{* *}$ & 1 & & \\
\hline CSE & 3.65 & .580 & $.514^{* *}$ & $.606^{* *}$ & $.702^{* *}$ & 1 & \\
\hline OCB & 3.65 & .474 & $.231^{*}$ & $.476^{* *}$ & $.479^{* *}$ & $.454^{* *}$ & 1 \\
\hline
\end{tabular}

*Correlation is significant at the 0.05 level (2-tailed); **Correlation is significant at the 0.01 level (2-tailed).

Table 4. Correlations among the dimensions of SI and OCB 
Table 4 represents the correlations among the dimensions of spiritual intelligence an OCB. The correlation matrix highlights the examined $\mathrm{OCB}$ and four sub-constructs which were critical existential thinking (CET), personal meaning production (PMP), transcendental awareness (TA) and conscious state expansion (CSE). According to the Table 4, all the constructs did not exceed the value of 0.75 . Hence, all the constructs were different and did not overlap with each other. Besides, there were positive correlations among all the constructs because none of the constructs had negative sign.

The regression analysis results of spiritual intelligence and OCB is highlighted in Table 5. The $p$-value of total spiritual intelligence with OCB is $0.000(P<0.05)$ which is significant. In this regard, hypothesis 1 is confirmed.

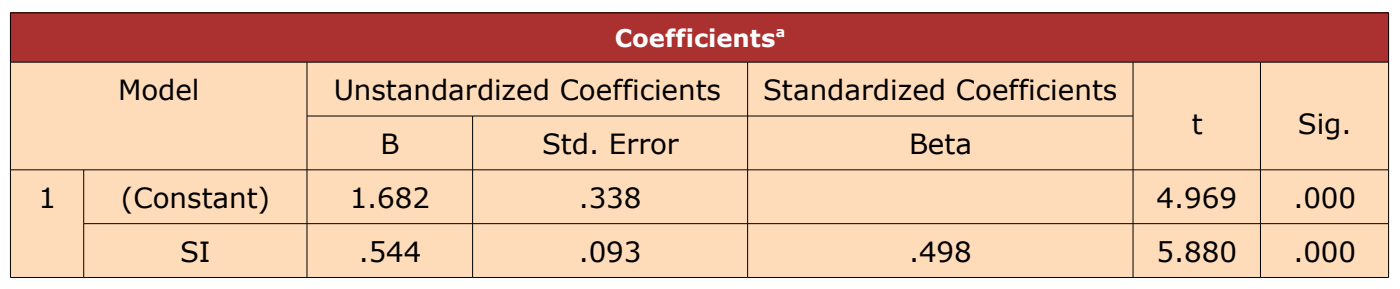

${ }^{\mathrm{a}}$ Dependent Variable: OCB

Table 5. Regression Analysis of the dimensions of SI and OCB

The regression analysis results of dimensions of spiritual intelligence and OCB is highlighted in Table 6. The $p$-value of with critical existential thinking (CET) with OCB is $0.116(p<0.05)$ which is not significant. The p-value of with personal meaning production (PMP) with OCB is $0.014(p<0.05)$ which is significant.

The $p$-value of with transcendental awareness (TA) with OCB is $0.022(p<0.05)$ which is significant. The $p$-value of with conscious state expansion (CSE) with OCB is 0.215 ( $p<0.05$ ) which is not significant. The results revealed that the hypothesis $1 \mathrm{a}$ and $1 \mathrm{~d}$ is rejected, where hypothesis $1 \mathrm{~b}$ and $1 \mathrm{c}$ is accepted.

\begin{tabular}{|c|c|c|c|c|c|c|}
\hline \multicolumn{2}{|c|}{\multirow{2}{*}{ Model }} & Unstandardized Coefficients & Standardized Coefficients & \multirow{2}{*}{ t } & \multirow{2}{*}{ Sig. } \\
\cline { 2 - 7 } & B & Std. Error & Beta & & \\
\hline \multirow{2}{*}{1} & (Constant) & 1.934 & .346 & & 5.583 & .000 \\
\cline { 2 - 7 } & CET & -.158 & .113 & -.146 & -1.396 & .166 \\
\cline { 2 - 7 } & PMP & .227 & .091 & .271 & 2.507 & .014 \\
\cline { 2 - 7 } & TA & .264 & .114 & .300 & 2.324 & .022 \\
\cline { 2 - 7 } & CSE & .126 & .101 & .155 & 1.248 & .215 \\
\hline
\end{tabular}

aDependent Variable: OCB

Table 6. Regression Analysis of the dimensions of SI and OCB 
From the above Table 5 and 6 , it can be observed that the effects of overall SI on organizational citizenship behaviour are statistically significant. On the other hand, the effects of CET $(P=0.166)$ and CSE $(P=0.215)$ are not significant $(p<0.05)$. So, the hypotheses $1 a$ and $1 \mathrm{~d}$ could not be confirmed. However, the effects of personal meaning production (PMP) and transcendental awareness $(\mathrm{TA})$ are found to be statistically significant (PMP $=.014$ and CSE $=0.022$, at $p<0.05)$. Hence, the results confirmed the hypotheses $1 \mathrm{~b}$ and $1 \mathrm{c}$.

\section{Discussions}

The results showed significant relationship existing among spiritual intelligence and organizational citizenship behaviour. Statistically significant relationships were found between two dimensions of Spiritual intelligence (e.g. personal meaning production, and transcendental awareness) with OCB. The results also support the research (Zohar \& Marshall, 2000). When SI is high in individuals, they appear to be intellectuals and they control behaviours in terms of their emotional experiences.

The means, standard deviations, zero-order correlations, and reliability coefficients provide a broad overview of the variables of study. Zero-order correlations provide an initial examination of the hypotheses linking spiritual intelligence and organizational citizenship behavior. The hypothesis stating positive relationship between SI and OCB is supported $(r=.49, p<.001)$ which is supported by George (2006), Dooster et al. (2012) and Moosapour, Feizi and Alipour (2013).

The study confirms that there is no relationship between critical existential thinking and OCB. People working in manufacturing and service industry are more concerning their job rather they can be free enough to contemplate among themselves their existence. Personal meaning production (PMP) and organizational citizenship behavior is positively correlated. The finding is suggested by George (2006). According to this the capacity to infer individual importance and reason from all physical \& mental encounters can influence the individual citizenship behaviour in the workplace. Additionally, the third sub-hypothesis presents that there is positive relationship between transcendental awareness and OCB. The hypothesis supported by Moosapour et al. (2013). And finally, the fourth sub hypothesis confirms that there is no relationship between conscious state expansion and OCB. CSE is the capacity to move around higher level of spiritual awareness at one's own discretion which might not have any influence on OCB in these industries.

The results indicated that SI and its two dimensions are positively related to $O C B$, this highlights the importance of matching predictors and criteria in terms of compatibility, both conceptually and empirically. Most of the previous studies on spiritual intelligence and organizational citizenship behavior were conducted in Western countries. The generalizability of 
these findings to other parts of the world is in question. More cross-cultural studies in this area of research are called for.

\section{Limitations and Suggestions for Future Research}

The concepts of spiritual intelligence have not been sufficiently studied in the field of Management, especially its influence on organizational citizenship behaviour. Further empirical research can make significant contributions to the field of Management research and practice. Scholars can develop new research agenda first to identify the nature of effects it might have on employee's performance which can boost the ultimate goal of the organization. For this reason, managerial levels of spiritual intelligence can be measured, and based on the findings, appropriate HRD interventions could be designed and implemented for improving employees' and organizational performance. Moreover, future researchers can also study the mediation effects of personal values and ethical behaviour in the relationship between SI, EI and organizational citizenship behaviour. Finally, the sample size of the study is considered small. Further research should be conducted in large sample thus it can provide better generalization. Hopefully, this paper would raise the levels of interests among scholars to conduct more spirituality related studies that may contribute to the new dimensions organizational management, particularly in the contexts of recent episodes of corporate scandals and ethical violations. In this regard, this research could be a stepping stone for conducting further studies in relevant fields of studies for advancing the knowledge.

\section{Implications}

Through the finding of this empirical study, it is hoped that it can provide some preliminary assessment and knowledge of the effects of spiritual intelligence of employees and how they relate to the OCB. This would be vital for various industrial sectors to develop relevant policies regarding enhancing employees' OCB. Findings from this study may create awareness and interest about the significance of SI and further studies can be developed to identify the extent of managerial intervention that may cater to the spiritual capabilities of the employees. It is also hoped that it may create awareness and interest among HRD officials in terms of recruitment and selection of people with these capabilities in the various industrial sectors. Employees would be concerned about the proper use and control of their spiritual awareness while they are in the job interacting with others. However, organizational citizenship behaviour can enhance the productivity of the employees, increase better commitment to job, and build strong interpersonal commitment among employees in the organization. The findings of the study would provide guidance of the need to use different strategies for the development of 
spiritual literacy taking into account the variable of the SI and OCB. Finally, this study would add to the literature on the study of spiritual intelligence and OCB.

\section{References}

Abdullah, A. (1996). Going glocal: Cultural dimensions in Malaysian management. Malaysian Institute of Management.

Aburdene, P. (2005). Megatrends 2010: The rise of conscious capitalism. Charlottesville: Hampton Roads Publishing Company.

Allameh, S.M., Amirosadat, S.N., \& Najafabadi, A.H.J. (2012). The Effect of dimensions of Spiritual intelligence on organizational justice in some industrial firms of Isfahan city. Journal of American Science, 8(8), 502-506.

Animasahun, R.A. (2007). Measured effect of emotional intelligence education in the remediation of aggressive behaviours among the members of the NURTW in Ibadan Metropolis. Ife Psychologia, 15(1), 128. http://dx.doi.org/10.4314/ifep.v15i1.23733

Borman, W.C., \& Motowidlo, S.J. (1997). Task performance and contextual performance: The meaning for personnel selection research. Human performance, 10(2), 99-109. http://dx.doi.org/10.1207/s15327043hup1002_3

Deluga, R.J. (1995). The relationship between attributional charismatic leadership and organizational citizenship behavior. Journal of Applied Social Psychology, 25(18), 1652-1669. http://dx.doi.org/10.1111/j.1559-1816.1995.tb02638.x

Doostar, M. Chegini, M.G. \& Pourabbasi, S. (2012). Survey of Relationship between Spiritual Intelligence and Organizational Citizenship Behavior. Institute of Interdisciplinary Business Research, 3(11), 54-61.

Emmons, R.A. (2000). Spirituality and intelligence: Problems and prospects. The International Journal for the Psychology of Religion, 10(1), 57-64. http://dx.doi.org/10.1207/S15327582IJPR1001_6

Faribors, B., Fatemeh, A. \& Hamidreza, H. (2010). The relationship between nurses' spiritual intelligence and happiness in Iran. Procedia Social and Behavioral Sciences, 5, 1556-1561. http://dx.doi.org/10.1016/j.sbspro.2010.07.325

Gardner, H. (1983). Frames of mind. New York: Basic Books.

Gardner, H. (1998). A multiplicity of intelligence. Scientific American, 9, 19-23.

George, M (2006). Practical application of spiritual intelligence in the workplace. Human Resource Management International Digest, 14(5), 3-5. 
Graham, J.W. (1991). An essay on organizational citizenship behavior. Employee Responsibilities and Rights Journal, 4, 249-270. http://dx.doi.org/10.1007/BF01385031

Hair Jr, J.F., Black, W.C., Babin, B.J., Anderson, R.E., \& Tatham, R.L. (2010). Multivariate data analysis. New Jersey, NJ: Pierson Hall.

Jahangir, N., Akbar, M.M., \& Haq, M., (2004). Organizational Citizenship Behavior: Its Nature And Antecedents. BRAC University Journal, I(2), 75-85

Jeloudar, S.Y. \& Goodarzi, F.L. (2012). What Is the Relationship between Spiritual Intelligence and Job Satisfaction among MA and BA Teachers? International Journal of Business and Social Science, 3(8), 299-303.

Kamil, N.M. (2012). Organizational citizenship behavior from Islamic Perspective and the role of Taqwa: Empirical analysis of business organizations in Malaysia. Unpublished doctoral dissertation, International Islamic University Malaysia, Kuala Lumpur.

King, D.B. (2008). Rethinking claims of spiritual intelligence: A definition, model, and measure. Unpublished Master's Thesis, Trent University, Petreborough, Ontario, Canada.

Kumar, A. \& Raj, L., (2009). Identification of Causes of Organizational Citizenship Behavior: A Qualitative study of LIC Managers. Indian Journal of Social Science Researches, 6(2), 17-28. ISSN: 0974-9837

Kwon Choi, B., Koo Moon, H., Ko, W., \& Min Kim, K. (2014). A cross-sectional study of the relationships between organizational justices and OCB: Roles of organizational identification and psychological contracts. Leadership \& Organization Development Journal, 35(6), 530-554. http://dx.doi.org/10.1108/LODJ-08-2012-0103

Lo, M.C., \& Ramayah, T. (2009). Dimensionality of organizational citizenship behavior (OCB) in a multicultural society: The case of Malaysia. International Business Research, 2(1), 48. http://dx.doi.org/10.5539/ibr.v2n1p48

Modassir, A., \& Singh, T. (2008). Relationship of Emotional Intelligence with Transformational Leadership and Organizational Citizenship Behavior, International Journal of Leadership Studies, 4(1), 3-21.

Moosapour, S., Feizi, M., \& Alipour, H. (2013). Spiritual Intelligence Relationship with Organizational Citizenship Behavior of High School Teachers in Germi City. Journal Of Business Management \& Social Sciences Research, 2(10), 72-75.

Noble, K.D. (2000). Spiritual intelligence: A new frame of mind. Advanced Development, 9, 1-29. 
Organ, D.W. (1988). Organizational Citizenship Behavior - The Good Soldier Syndrome. 1st ed. Lexington, Massachusetts/Toronto: D.C. Heath and Company.

Organ, D.W. (1990). The motivational basis of organizational citizenship behavior. Research in Organizational Behavior, 12, 43-72.

Organ, D.W., Podsakoff, P.M., \& MacKenzie, S.B. (2006). Organizational citizenship behavior: Its nature, antecedents, and consequences. London: Sage Publications.

Osman-Gani, A.M., \& Sarif, S.M. (2011). Spirituality in Management from Islamic Perspective. Kuala Lumpur: KL, Malaysia: IIUM Press.

Osman-Gani, A.M., Hashim, J., \& Ismail, Y. (2013). Establishing linkages between religiosity and spirituality on employee performance. Employee Relations, 35(4), 360-376.

http://dx.doi.org/10.1108/ER-04-2012-0030

Osman-Gani, M.A. \& Anwar, A. (2014). Effects of Spiritual Intelligence on Employee Performance, Mediated by Organizational Citizenship Behavior: A Conceptual Analysis. The Proceedings of AHRD International Research Conference in the Americas. Houston, Texas, USA.

Osman-Gani, M.A., \& Anwar, A. (2013). Impact of Spiritual Intelligence and Emotional Intelligence on Employee Performance: A Conceptual Analysis, The proceedings of 20th Annual AHRD International Research Conference in the America. Washington D.C, USA.

Podsakoff, P.M., MacKenzie, S.B., Paine, J.B., \& Bachrach, D.G. (2000). Organizational citizenship behaviors: A critical review of the theoretical and empirical literature and suggestions for future research. Journal of Management, 26, 513-563.

http://dx.doi.org/10.1177/014920630002600307

Saidy E.P., Hassan A., Rahman F.A., Jalil H.A., Ismail I.A., \& Krauss S.E. (2009). Influence of Emotional and Spiritual Intelligence from the National Education Philosophy Towards Language Skills Among Secondary School Students. European Journal of Social Sciences, $9(1)$.

Salehi, M., \& Gholtash, A. (2011). The relationship between job satisfaction, job burnout and organizational commitment with the organizational citizenship behavior among members of faculty in the Islamic Azad University-first district branches, in order to provide the appropriate model. Procedia-Social and Behavioral Sciences, 15, 306-310.

http://dx.doi.org/10.1016/j.sbspro.2011.03.091

Shabani, J., Hassan, S.A., Ahmad, A., \& Baba, M. (2011). Moderating Effect of Age on the Link of Emotional Intelligence and Mental Health among High School Students. International Education Studies, 4(2), 82. http://dx.doi.org/10.5539/ies.v4n2p82 
Smith, C.A., Organ, D.W., \& Near, J.P. (1983). Organizational citizenship behavior: Its nature and antecedents. Journal of Applied Psychology, 68, 653-663. http://dx.doi.org/10.1037/00219010.68 .4 .653

Sonboli, A.R.H. \& Noruzi, M.R. (2012). A study on the relationships between employees' multiple intelligences and organizational citizenship behavior in Islamic Azad University Locale 13. Australian Journal of Basic and Applied Sciences, 6(10), 316-322.

Weller, L.D. (1999). Application of the multiple intelligences theory in quality organizations. Team Performance Management, 5(4), 136-146.

http://dx.doi.org/10.1108/13527599910283493

Wigglesworth, C. (2002). Spiritual Intelligence and Why it Matters. Bellaire TX.: Conscious Pursuit Inc.

Williams, L.J., \& Anderson, S.E. (1991). Job satisfaction and organizational commitment as predictors of organizational citizenship and in-role behaviors. Journal of Management, 17, 601-617. http://dx.doi.org/10.1177/014920639101700305

Zohar, D., \& Drake, J. (2000). Learning Centre - Develop your spiritual intelligence and become a better leader. People management: the magazine for professionals in personnel, training and development. London: Personnel Publication, 6(8), 55-56.

Zohar, D., \& Marshall, I. (1997). Who's Afraid of Schrodinger's Cat. London: Bloomsbury.

Zohar, D., \& Marshall, I. (2000). SQ: Connecting with our spiritual intelligence. New York, NY: Bloomsbury.

Zohar, D., \& Marshall, I. (2004). Spiritual capital: Wealth we can live by. London: Bloomsbury Publishing.

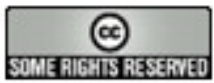

Article's contents are provided on a Attribution-Non Commercial 3.0 Creative commons license. Readers are allowed to copy, distribute and communicate article's contents, provided the author's and Journal of Industrial Engineering and Management's names are included. It must not be used for commercial purposes. To see the complete license contents, please visit http://creativecommons.org/licenses/by-nc/3.0/. 